\title{
Electrochemical Determination of Furosemide Drug at Tranexamic Acid Gold Nanoparticles Modified Glassy Carbon Electrode
}

\author{
Tasawar Ali Chandio ${ }^{1}$, Ozcan Yalcinkaya ${ }^{1} *$, M. Nasiruddin Khan $^{2}$, \\ Elif Calik Kayis ${ }^{3}$, Atya Hassan ${ }^{4}$ and Ahmet Furkan Kayis ${ }^{1}$ \\ ${ }^{1}$ Department of Chemistry, Faculty of Science, Gazi University, Ankara 06500, Turkey. \\ ${ }^{2}$ Department of Chemistry, University of Karachi, Karachi 75270, Pakistan. \\ ${ }^{3}$ Department of Analytical Chemistry, Faculty of Pharmacy, Gazi University, Ankara 06330, Turkey. \\ ${ }^{4}$ Department of Chemistry, Federal Urdu University of Arts, Sciences \& Technology, Karachi - 75300, Pakistan. \\ *Corresponding Author Email: oyalcinkaya@gazi.edu.tr \\ Received 07 October 2020, Revised 30 April 2021, Accepted 02 May 2021
}

\begin{abstract}
The reported work discussed the simpler and sensitive strategy for the electrochemical determination of furosemide by employed tranexamic acid derived gold nanoparticles modified glassy carbon electrode (GCE). The synthesis of tranexamic acid derived gold nanoparticles (TrAuNps) was carried out using single step approach. The synthesized Tr-AuNps were characterized by using atomic force microscopy (AFM), illustrated that the particles are spherical in shape with an average size of $35 \mathrm{~nm}$. The synthesized AuNps have modified the sensing surface of GCE. The modified GCE demonstrated highly catalytic behavior for the oxidation of loop diuretic drug furosemide. The influence of $\mathrm{pH}$ and supporting electrolyte was examined and the working conditions were optimized. The amperometric determination of furosemide was also carried out at the Tr-AuNps modified GCE under stirred conditions using Britton Robinson buffer (BR buffer) as supporting electrolyte at $\mathrm{pH}$ 5. The linear calibration plot showed the dependence of the peak current on increasing concentrations of furosemide in the range of $50 \mu \mathrm{M}$ to $500 \mu \mathrm{M}$ furosemide with the detection limit of $5 \mu \mathrm{M}$. The proposed sensing plan has been successfully employed for the quantification of furosemide in human urine samples with satisfactory recoveries.
\end{abstract}

Keywords: Furosemide, Tranexamic acid gold nanoparticles, Amperometric, Glassy Carbon Electrode.

\section{Introduction}

Furosemide is commonly known as frusemide, which is a derivative of anthranilic acid inclusion to the class of compounds designated as high-ceiling diuretics [1]. Furosemide (4-chloro-N-furfuryl-5-sulfamoylanthranilic acid, is primarily labelled antibacterial agent as sulfonamide [2]. Owing to its fast and powerful diuretic results, this drug has prolonged usages as a prevailing acidic diuretic in veterinary medicine and humans [3]. Its prime action is also classified as a loop diuretic, which prevents the vigorous reabsorption of chloride in the diluting segment of the loop of Henle [4-6]. This drug was primarily used for the control of hypertension and later, it has found uses in the cure of edema related to nephrotic syndrome, heart failure, cirrhosis of renal and liver disease [7- 10]. The International Olympic Committee of Medical Commission in 1986 has banned all diuretics as well as furosemide in sports. In this regard, health experts in most 
countries have already ruled out the constituent for the manufacture of drugs for bodyweight reduction. This compound caused weight loss by increasing the flow of urine. It is also used in the production of illegal drugs to lose weight in women and caused health issues in some cases in China [7].

Furosemide is a white or slightly yellow powder. It is frequently solvable in organic solvents i.e. methanol and acetone as well as in alkaline aqueous solutions. It is sparingly solvable in aqueous acidic solutions [11]. Its half-life in the blood plasma is about 1-2 $\mathrm{h}$ and bioavailability ranges from 60 to 70 $\%$ [12]. The structural formula of the drug is given below:<smiles>NS(=O)(=O)c1cc(C(=O)O)c(NCc2ccco2)cc1Cl</smiles>

Furosemide

Large numbers of analytical procedures have been published for the endurance of furosemide in biological fluids and pharmaceutical products. These including spectrofluorimetry [13-18], titrimetry [19], spectrophotometry, [20-25], Liquid chromatography (LC) $[20,26,27]$, simultaneous determination of diuretics by HPLC-EC [28], micellar electrokinetic chromatographic methods [29], HPLC methods [12,15, 30,31], capillary electrophoresis [32], variable-angle scanning fluorescence spectrometry, [33], potentiometry, GC-MS [34], voltammetry [35], glassy carbon electrode [36], carbon fiber microelectrodes [37], capillary electrophoresis [38], flow-injection, gold electrode, hanging mercury drop electrode [39], graphite electrode [1] and multi-walled carbon nanotubes-paraffin oil paste electrode
[10]. Most of the above described methods involve the extraction, preparation of the sample and the use of toxic solvents. They are also time consuming or require expensive equipment. Thus, the development of an efficient and effective method for the quantification of furosemide in biological fluids and pharmaceutical preparation is a substantial imposition. Nowadays, electrochemical techniques have led to advances in the analysis due to their relatively short analysis time, sensitivity and low cost. The proposed electrochemical method has advantage over the available developed methods, owing to its low detection limit and experimental simplicity, relatively inexpensive, fast response, ultra-high sensitivity, selectivity and relatively and remarkable detectability.

In the presented work, the determination of furosemide has been done by using a glassy carbon electrode (GCE) modified with gold nanoparticles and nafion, and the suitability has been investigated.

Correct sequence of references from 34-40

\section{Materials and Methods Chemicals and Reagents}

Analytical grade potassium chloride, acetic acid, hydrochloric acid, sodium hydrogen phosphate and disodium hydrogen phosphate reagents of E. Merck, Germany were used in the study. The standard for furosemide drug was obtained from Natural Pharma Brazil. $1 \mathrm{mM}$ stock solution of furosemide was prepared in HPLC grade methanol and stored under refrigeration $\left(4{ }^{\circ} \mathrm{C}\right)$ in the dark. Further diluted solutions of $\left(10^{-4}\right.$ to $10^{-6} \mathrm{mM}$ ) were prepared from a stock solution. BR buffer (mixture of boric acid, phosphoric acid and acetic acid), acetate buffer and chloride buffer solutions were used as supporting electrolyte. In order to obtain the appropriate $\mathrm{pH}$ value, buffer solutions 
were adjusted by adding the necessary amounts of $\mathrm{HCl}$ or $\mathrm{KOH}$.

\section{Instrumentation}

Electrochemical measurements were performed on Trace Analyzer (VA 797 of Metrohm version 1.1 Switzerland) with a personal computer together with a conservative three-electrode cell. Threeelectrode scheme consisted of an $\mathrm{Ag} / \mathrm{AgCl}$ $(3 \mathrm{M} \mathrm{KCl})$ as reference electrode, a platinum wire as an auxiliary electrode and self-made gold nanoparticles and nafion modified GCE was used as working electrode. Analytical grade balance (Switzerland) was used for weighing the solid materials. The $\mathrm{pH}$ studies were carried out using a $781 \mathrm{pH} /$ ion meter of Metrohm with an internal reference electrode and glass electrode. For the transfer of analyte solutions, micro-pipette (Eppendorf Multipette plus) was used. The deionized water, purified with a Milli-Q Plus system (Millipore) was used throughout the study. An ultrason unique (ultrasonic model) was used for dissolution of all other reagents and furosemide. AFM studies were conducted by using an Agilent 5500, atomic force microscope, USA. This instrument is beneficial for imaging of dried deposits of AuNps or other species and is also capable of providing a 3-D image of the analytical species.

\section{Synthesis of Tranexamic Acid Derived AuNps}

The synthesis of tranexamic acid derived AuNps was carried out according to the reported work [43]. $5 \mathrm{~mL}$ of deionized water was added to $200 \mu \mathrm{L}$ of $0.2 \mathrm{M} \mathrm{NaOH}$ with the subsequent addition of $150 \mu \mathrm{L}$ of $0.5 \% \mathrm{HAuCl}_{4}$ and $120 \mu \mathrm{L}$ of $0.5 \%$ tranexamic acid solutions. The resultant solution was heated at $150^{\circ} \mathrm{C}$ under constant shaking at 200 rpm till the color of the solution turned red wine, indicating the formation AuNps.

\section{Sample Preparation for AFM}

To investigate the morphological features of the synthesized Tr-AuNps, $100 \mu \mathrm{L}$ of the solution of Tr-AuNps was placed over mica slide and evaporated to a thin film. The film was subjected to AFM imaging.

\section{Results and Discussion \\ AFM Characterization of Tr-AuNps}

Various techniques are used for the characterization / morphological studies of nanoparticles. These techniques are helpful to examine the accumulation and dispersion of nanoparticles. For this purpose, three dissimilar scanning modes are available, including intermittent sample contact mode, non-contact mode, and contact mode for their size, structure, sorption and shape. The morphological features of Tr-AuNps were studied using AFM. It can be clearly seen (Fig. 1) that the synthesized AuNps are spherical in shape and possess an average diameter of around $35 \pm \mathrm{nm}$.

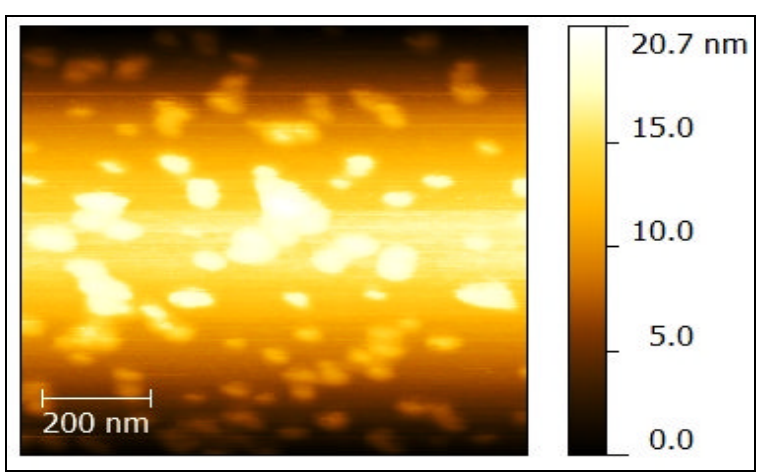

Figure 1. AFM image of the Tr-AuNps

\section{Electrochemical Oxidation of Furosemide at Bare and Modified GCE}

Furosemide electrochemical behavior was examined at bare and $\mathrm{Tr}-\mathrm{AuNps}$ modified GCE at pH 5 in BR buffer (0.04 M). The oxidation behavior of furosemide showed no cathodic peak in the reverse scan, while 
one anodic peak in the positive scan was observed.

The comparative voltammograms are shown in Fig. 2. It is evident that as the concentration of furosemide increases, there is an increase in peak current value in the case of Tr-AuNps modified GCE in comparison to bare GCE. This clearly indicates the electrocatalytic nature of Tr-AuNps for furosemide.

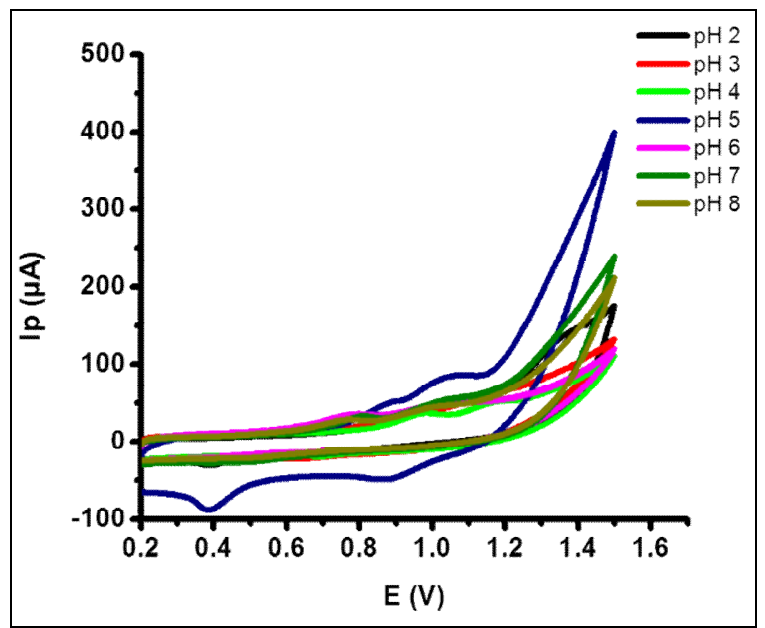

Figure 2. Cyclic voltammograms recorded in $0.04 \mathrm{M}$ BR buffer pH 4 with the absence (a) bare GCE, (b) Tr-AuNps modified GCE , and in the presence of $0.125 \mathrm{mM}$ furosemide (c) bare GCE, (d) Tr-AuNps modified GCE with scan rate $0.05 \mathrm{Vs}^{-1}$

\section{Influence of $\mathrm{pH}$}

The $\mathrm{pH}$ effect was also studied for the voltammetric determination of furosemide using BR buffer $(0.04 \mathrm{M})$ as a supporting electrolyte. The influence of $\mathrm{pH}$ was monitored in the range of $\mathrm{pH} 2$ to 8 . The influence of $\mathrm{pH}$ on peak current and peak shape is shown in Fig. 3. It could be observed that an increase in $\mathrm{pH}$ leads to the abrupt shift of peak potential and peak current, as well as. This may be due to the solubility of analytes. The highest peak current was observed at $\mathrm{pH} 5$ due to better current response, $\mathrm{pH} 5$ was selected for subsequent studies and considered as optimized $\mathrm{pH}$.

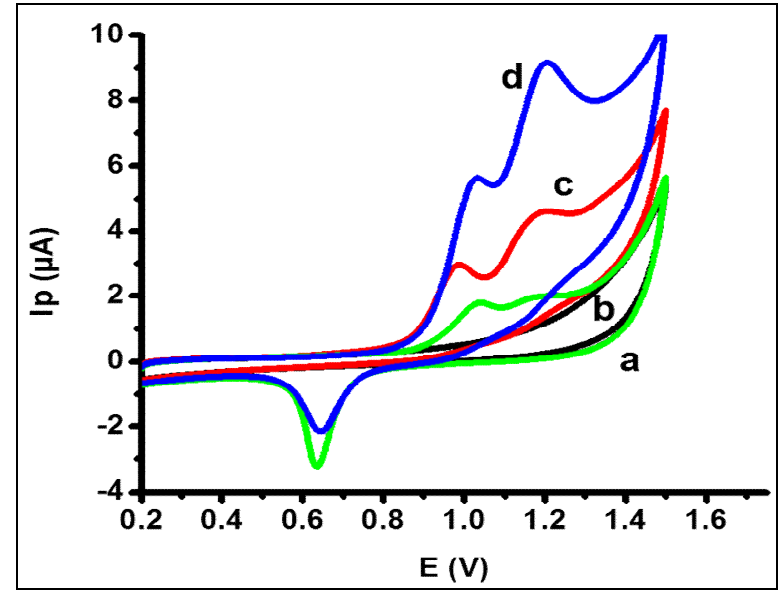

Figure 3. Cyclic voltammograms of furosemide $(0.125 \mathrm{mM})$ with Tr-AuNps modified GCE electrode in BR buffer $(0.04 \mathrm{M})$ with 2 to $\mathrm{pH} 8$ used as supporting electrolyte.

\section{Influence of Supporting Electrolyte}

To study the influence of supporting on the current sensitivity marked medium of surrounding, three different kinds of buffer, such as acetate buffer $(0.1 \mathrm{M})$, chloride buffer $(0.1 \mathrm{M})$ and BR buffer $(0.04 \mathrm{M})$ were used as supporting electrolytes. In acetate buffer system (pH-5) showed no anodic peak. Despite acetate buffer, chloride and BR buffer gave good responses, as shown in Fig. 4. It was noticed that the highest sensitivity response was observed at BR- buffer and was selected for further studies.

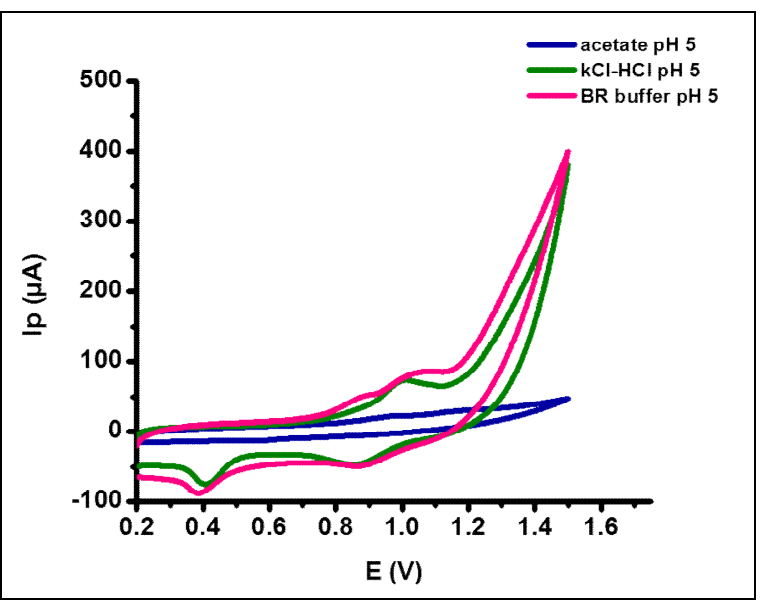

Figure 4. Cyclic voltammograms recorded with $0.125 \mathrm{mM}$ furosemide in different buffers i.e., BR buffer, acetate and $\mathrm{KCl}$ HCl buffer each at pH 5 . 


\section{Amperometric Determination of Furosemide at Tr-AuNps Modified GCE}

The amperometric response of the $\mathrm{Tr}$ AuNps modified GCE was observed for the oxidation of furosemide in $0.04 \mathrm{M} \mathrm{pH} 5 \mathrm{BR}$ buffer under stirring at $0.8 \mathrm{~V}$. Fig. 5 shows that i-t curve for the stepwise addition of furosemide in BR buffer, each addition of 0.1 $\mathrm{mL}$ leading to an increment of $50 \mu \mathrm{M}$ of furosemide concentration. A plot of peak current versus concentration is illustrated in the inset of Fig. 4 that follows a linear relationship in the range of 50 furosemide to $450 \mu \mathrm{M}$. The detection limit was found to 5 $\mu \mathrm{M}$.
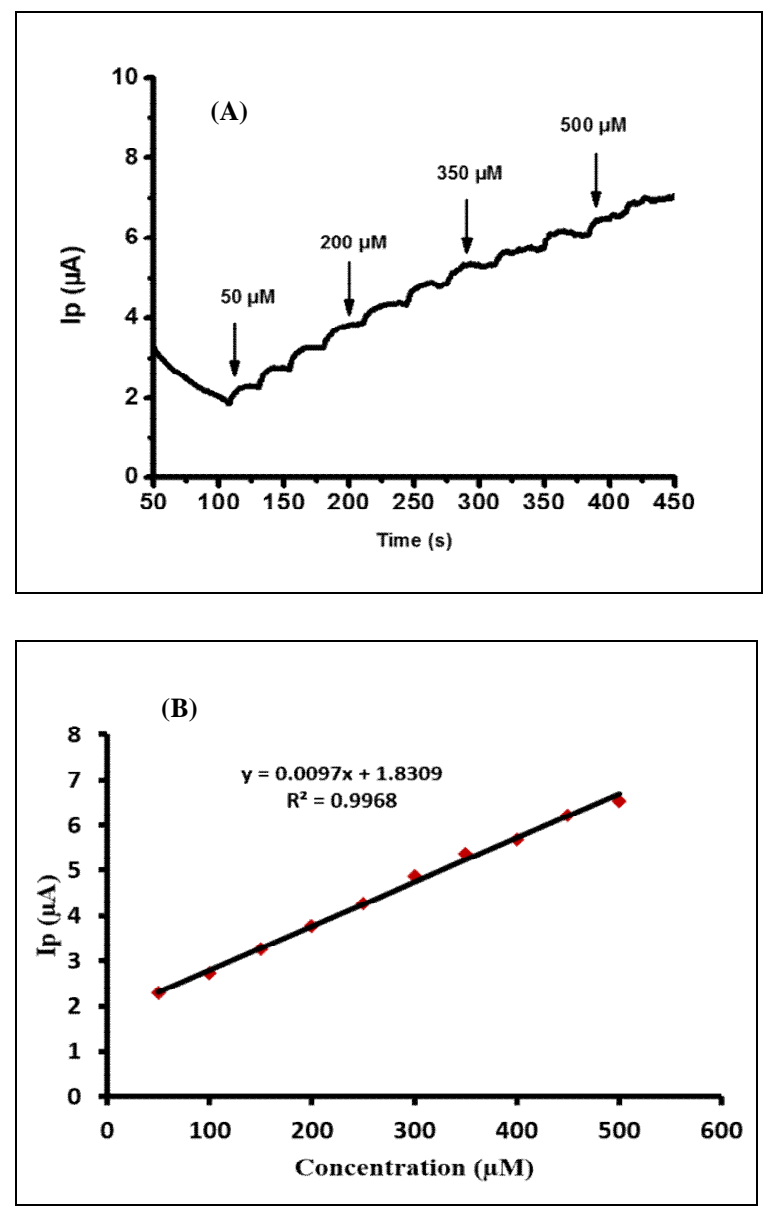

Figure 5. (A) Amperometric current- time response curves for the successive addition of furosemide solution in stirred BR buffer $0.04 \mathrm{M}$ pH 5 under applied potential of $0.8 \mathrm{~V}$ (B) the corresponding calibration plot for the dependence of peak current on furosemide concentration.

\section{Comparative study}

The present study was compared with the reported methods in the literature was shown in the Table 1.

Table 1. Electroanalytical procedures for determination of furosemide in the literature.

\begin{tabular}{|c|c|c|c|}
\hline Detection & Media & $\begin{array}{c}\text { LOD } \\
\left(\mathrm{mol} \mathrm{dm}^{-3}\right)\end{array}$ & Ref \\
\hline $\begin{array}{l}\text { Amperometric } \\
\text { detection at a } \mathrm{GCE} \\
(+1.3 \mathrm{~V} \text { vs. } \mathrm{Ag} / \mathrm{AgCl}) \\
\text { coupled to HPLC }\end{array}$ & $\begin{array}{l}\text { Water- } \\
\text { acetonitrile } \\
(30: 70)\end{array}$ & $4.5 \times 10^{-8}$ & [28] \\
\hline $\begin{array}{l}\text { Amperometric } \\
\text { detection at carbon } \\
\text { fiber microelectrodes } \\
(+1.25 \mathrm{~V} \text { vs. } \mathrm{Ag} / \mathrm{AgCl}) \\
\text { coupled to } \mathrm{HPLC} \text { and } \\
\text { FIA }\end{array}$ & $\begin{array}{l}\text { Acetonitrile- } \\
\text { water } \\
(25: 75), 5 \\
\text { mmol L-1 } \\
\text { NaH2PO4 } \\
\text { (HPLC), } 5 \\
\text { mmol L-1 } \\
\text { NaH2PO4 } \\
\text { (FIA) }\end{array}$ & $5.5 \times 10^{-7}$ & [40] \\
\hline $\begin{array}{l}\text { Voltammetric } \\
\text { detection at } \\
\text { GCE } \\
(+1.2 \mathrm{~V} \text { vs. } \mathrm{Ag} / \mathrm{AgCl})\end{array}$ & $\begin{array}{l}\text { Methanol- } \\
\text { water } \\
(10: 90)\end{array}$ & $1.5 \times 10^{-7}$ & [28] \\
\hline $\begin{array}{l}\text { Graphite polyurethane } \\
\text { composite } \\
\text { electrode }(+1.0 \mathrm{~V} \text { vs. } \\
\text { SCE) }\end{array}$ & $\begin{array}{c}1.0 \mathrm{mmol} \mathrm{L}^{-1} \\
\mathrm{NaOH}\end{array}$ & $2.8 \times 10^{-6}$ & [41] \\
\hline $\begin{array}{l}\text { Multi-walled carbon } \\
\text { nanotubes-paraffin } \\
\text { Oil paste electrode }\end{array}$ & $\begin{array}{c}\text { Methanol - } \\
\text { water (10:90) }\end{array}$ & $2.9 \times 10^{-7}$ & [42] \\
\hline $\begin{array}{l}\text { Electrochemical } \\
\text { oxidation at gold } \\
\text { electrode }\end{array}$ & $\begin{array}{l}\text { Methanol- } \\
\text { Water } \\
(10: 90)\end{array}$ & $4.12 \times 10^{-8}$ & [43] \\
\hline $\begin{array}{l}\text { Voltammetric } \\
\text { determination at } \\
\text { GCE modified with } \\
\text { gold nano particles }\end{array}$ & $\begin{array}{c}\text { Buffer } \\
\text { System } \\
\text { (RB- Buffer } \\
\text { \& Chloride } \\
\text { Buffer }\end{array}$ & $5 \times 10^{-6}$ & $\begin{array}{c}\text { Present } \\
\text { Work }\end{array}$ \\
\hline
\end{tabular}

\section{Interference Study}

The effect of multiple ions on the peak current of furosemide oxidation was also examined. Several interfering species such as citric acid, ascorbic acid, glucose, $\mathrm{Na}^{+}, \mathrm{Pb}^{+}$, $\mathrm{Cl}^{-}$, and drugs such as paracetamol, diflunisal, piroxicam were added in equimolar ratios with 
that of emide and change in signal for oxidation of furosemide was observed. Peak current value was considered as $100 \%$ for the oxidation of furosemide in the absence of interfering ions and then change in peak current was observed after the addition of interfering species into the solution. \% interference was calculated to observe the effect of various interfering species on the peak current of furosemide using the amperometric technique (Table 2). The results show that there was no appreciable interference observed and thus verified the validity of the proposed method for the analysis of furosemide in real samples. \% interference was found below 5\% for each interfering species.

Table 2. Influence of interfering species for the amperometric determination of furosemide.

\begin{tabular}{lc}
\hline Interferents & Interference (\%) \\
\hline Glucose & +1.5 \\
Citric acid & +0.5 \\
Uric acid & +2 \\
Piroxicam & +2.2 \\
Cephalothin & +0.98 \\
Paracetamol & +0.15 \\
\hline
\end{tabular}

\section{Analysis of Furosemide in Real Samples}

The applicability of the proposed method was checked in human urine samples. Before analysis, the urine samples were diluted 10 times with BR buffer. The standard furosemide solution for spiking of diluted samples was used to calculate \% recovery values. Each sample was analyzed three times and the average was calculated and presented in Table 3. The values of $\%$ recovery ranges from $99.4 \%$ to $100.7 \%$ that indicates the applicability of the method to human urine samples.
Table 3. Determination of Furosemide in human urine samples using recovery test $(n=3)$.

\begin{tabular}{cccccc}
\hline Samples & $\begin{array}{c}\text { Detected } \\
(\boldsymbol{\mu M})\end{array}$ & $\begin{array}{c}\text { Spiked } \\
(\boldsymbol{\mu M})\end{array}$ & $\begin{array}{c}\text { Found } \\
(\boldsymbol{\mu M})\end{array}$ & $\begin{array}{c}(\%) \\
\text { Recovery }\end{array}$ & $\begin{array}{c}(\%) \\
\text { RSD }\end{array}$ \\
\hline Urine 1 & 150 & 100 & $248.5 \pm 0.08$ & 99.4 & 1.5 \\
Urine 2 & 250 & 100 & $350.8 \pm 0.02$ & 100.2 & 1.25 \\
Urine 3 & 350 & 100 & $453.2 \pm 0.04$ & 100.7 & 2.5 \\
\hline
\end{tabular}

\section{Conclusion}

The current study proposed a fast and simple analytical process for the quantification of furosemide using Tr-AuNps. In this research work, GCE was modified with TrAuNps. AFM technique was used to find the shape and size of nanoparticles. The adopted strategy favors the catalytic oxidation of furosemide at the Tr-AuNps and minimizing the need for time consuming methods for the analysis of furosemide. The detection limit of $5 \mu \mathrm{M}$ for furosemide estimation was observed in modified GEC. This method can also be used for the quantification of furosemide in human urine samples as an alternate means to check the toxicity of furosemide in the patients taking this drug.

\section{Conflict of Interest}

The authors declare that there is no conflict of interest.

\section{References}

1. S. Felipe, M. Edilson, T. G. Eder and M. Christopher, Electroanalysis, 20 (2008) 2287. https://doi.org/10.1002/elan.200804329

2. M. J. Ruiz-Angel, A. Berthod, S. CardaBroch and M. C. Garcia-AlyarezCoque, Sep. Purif. Rev., 35 (2006) 39. doi: 10.1080/15422110600671726.

3. S. O. Alberto, R. P. Helena, S. Rodrigo, R. L. José, and P. Leonardo J. Braz. Chem. Soc., 20 (2009) 64. http://dx.doi.org/10.1590/S0103$\underline{50532009000100012}$ 
4. K. Govind, R. Vijay, M. Kher and J. Hitendra, Res. J. Pharm. Biol. Chem., 4 (2013) 365,

ISSN: 0975-8585.

5. M. Toral, P. Stefanie, Q. Silvia and R. Pablo, Int. J. Pharm., 249 (2002) 117. doi: 10.1016/s0378-5173(02)00482-9.

6. E. Berardesca, P. Gabba, G. Ucci, G. Borroni and G. Rabbiosi, Int. J. Tissue React., 10 (1988) 115.

PMID: 2972662.

7. Y. Rao, Z. Xinrong, L. Guoan and R. Willy, Anal. Chim. Acta, 396 (1999) 273. http://hdl.handle.net/1854/LU-121106.

8. M. A. Gotardo, A. C. Gigante, L. Pezza and H. R. Pezza, Talanta, 64 (2004) 361. https://doi.org/10.1016/j.talanta.2004.02.034

9. L. S. Goodman, A. Gilman, The pharmacological basis of therapeutics. McGraw-Hill, New York (2001).

10. J. M. Shweta, C. A. Jyothi, P. S. Nagaraj and T. N. Sharanappa, Electrochim. Acta, 60 (2012) 95.

https://doi.org/10.1016/j.electacta.2011.11.0 $\underline{11 .}$

11. S. Felipe, A. Paulo and T. Eder, Anal. Lett., 41 (2008) 66.

https://doi.org/10.1080/00032710701746782.

12. E. S. Waller, S. F. Hamilton, J. W. Massarella, M. A. Sharanevych, R. V. Smith, G. J. Yakatan and J. T. Doluisio, J. Pharm. Sci., 71 (1982) 1105. doi: $10.1002 / j$ ps. 2600711006.

14. P. C. Ioannou, N. V. Rusakova, D. A. Andrikopoulou, K. M. Glynoy, G. M. Tzompanaki, Analyst, 123 (1998) 2839. doi: 10.1039/A806093B.

13. M. L. Luis, J. M. Fraga, A. I. Jiménez, O. Hernández and J. J. Arias, Talanta, 62 (2004) 307. https://doi.org/10.1016/j.talanta.2003.07.010

15. Y. S. El-Saharty, J. Pharm. Biomed. Anal., 33 (2003) 699. https://doi.org/10.1016/S07317085(03)00229-2.
16. I. Baranowska, P. Markowski and J. Baranowski, J. Anal. Chim. Acta, 570 (2006) 46. doi: 10.1016/j.aca.2006.04.002.

17. B. Shaikh, J. Agric. Food Chem., 43 (1995) 2117. doi: 10.1021/jf00056a029.

18. S. Carda-Broch, J. Esteve-Romero, M. J. Ruiz-Angel and M. C. Alvarez-Coque, Analyst, 127 (2002) 29. doi: 10.1039/B108358A.

19. M. Abdel-Hamid, IL Farmaco, 55 (2000) 448. https://doi.org/10.1016/S0014$\underline{827 X(00) 00064-1}$

20. A. A. Nava-Ocampo, E. Y. VelázquezArmenta, H. Reyes-Pérez, E. RamirezLopez and H. Ponce-Monter, J. Chromatogr. B, 730 (1999) 49. https://doi.org/10.1016/S03784347(99)00176-0

21. F. Y. Tsai, L. F. Lui and B. Chang, $J$. Pharm. Biomed. Anal., 9 (1991) 1069. doi: 10.1016/0731-7085(91)80046-c.

22. M. Saugy, P. Meuwly, A. Munafo and L. Rivier, J. Chromatogr. B, 564 (1991) 567.

https://doi.org/10.1016/03784347(91)80525-H

23. H. Hagedorn, R. Schulz, J. Anal. Toxicol., 16 (1992) 194. https://doi.org/10.1093/jat/16.3.194.

24. M. L. Riekkola, J. H. Jumppanen, $J$. Chromatogr. A, 735 (1996) 151. https://doi.org/10.1016/00219673(95)01267-2.

25. S. D. Bukkitgar and N. P. Shetti, Cogent Chem., 2 (2016) 1152784. http://dx.doi.org/10.1080/23312009.201 $\underline{6.1152784}$

26. S. Carda-Broch, J. Esteve-Romero and M. C. García-Alvarez-Coque, J. Pharm. Biomed. Anal., 23 (2000) 803. doi: 10.1016/s0731-7085(00)00378-2 
27. M. C. F. Ferraro, P. M. Castellano and T. S. Kaufman, J. Pharm. Biomed. Anal., 26 (2001) 443. doi: 10.1016/s0731-7085(01)00432-0.

28. M. B. Barroso, R. M. Alonso and R. M. Jimenez, J. Chromatogr. Rel. Technol., 19 (1996) 231.

https://doi.org/10.1080/10826079608005 509

29. J. Polsluszny and R. Weinberger, Anal. Chem., 60 (1998) 1953. https://doi.org/10.1021/ac00169a023

30. R. S. Rapaka, J. Roth and V. K. Prasad, Int. J. Pharm., 11 (1982) 237. https://doi.org/10.1016/03785173(82)90042-

31. M. G. Quaglia, E. Bossu, C. Desiderio and S. Fanalis, IL Farmaco, 49 (1994) 403.

ISSN: 978-3-322-85011-9

32. F. Garcia Sanchez, A. Fernandez Gutierrez and C. Cruces Blanco, Anal. Chim. Acta, 306 (1995) 313. https://doi.org/10.1016/00032670(94)00689-J

33. D. Carreras, C. Imaz, R. Navajas, M. A. Garcia, C. Rodriguez, A. F. Rodriguez and R. Cortes, J. Chromatogr. A, 683 (1994) 195.

https://doi.org/10.1016/S00219673(94)89116-8

34. Nikolić, Katarina, Medenica, Mirjana, Acta Pharm. Jugosl. Zagreb, 40 (1990) 521.

http://farfar.pharmacy.bg.ac.rs/handle/12 3456789/71.
35. M. B. Barroso, R. M. Alonso and R. M. Jiménez, Anal. Chim. Acta, 305 (1995) 332.

https://doi.org/10.1016/00032670(94)00373-T

36. Y. S. El-Saharty, J. Pharm. Biomed. Anal., 33 (2003) 699.

https://doi.org/10.1016/S07317085(03)00229-2

37. B. Shaikh, J. Agric. Food Chem., 43 (1995) 2117. https://doi.org/10.1021/jf00056a029.

38. M. B. Barroso, R. M. Alonso and R. M. Jimenez, J. Liquid Chromatogr. Rel. Technol., 19 (1996) 231. https://doi.org/10.1080/10826079608005 $\underline{509 .}$

39. P. S. Nagaraj, V. S. Lokesh, N. H. Rajesh and T. N. Sharanappa, Int. J. Electrochem. Sci., 4 (2009) 104. doi:10.1016/j.carbpol.2009.03.007

40. I. S. Mohamed, H. R. Azza and A. M.A. Fatma, RSC Adv., 8 (2018) 18698. doi: $10.1039 / \mathrm{c} 8 \mathrm{ra} 02978 \mathrm{~d}$.

41. S. Amin and G. H. Ragab, Anal. Sci., 19 (2003) 747.

https://doi.org/10.2116/analsci.19.747

42. S. Felipe, M. Edilson, T. G. Eder and M. Christopher. Electroanalysis, 20 (2008) 2287. https://doi.org/10.1002/elan.200804329

43. J. M. Shweta, C. A. Jyothi, P. S. Nagaraj and T. N. Sharanappa, Electrochim. Acta, 60 (2012) 95. http://doi.org/10.1016/j.jelectro.2012.04. $\underline{006 .}$. 